\title{
Electricity and Heat Production by Biomass
}

\author{
Simon Marčič, Milan Marčič, Zdravko Praunseis \\ Faculty of Energy Technology, University of Maribor, Maribor, Slovenija \\ Email: milan.marcic@um.si
}

How to cite this paper: Marčič, S., Marčič, M. and Praunseis, Z. (2016) Electricity and Heat Production by Biomass. Natural Resources, 7, 666-675.

http://dx.doi.org/10.4236/nr.2016.711053

Received: September 28, 2016

Accepted: November 27, 2016

Published: November 30, 2016

Copyright $\odot 2016$ by authors and Scientific Research Publishing Inc. This work is licensed under the Creative Commons Attribution International License (CC BY 4.0).

http://creativecommons.org/licenses/by/4.0/ (c) (i) Open Access

\begin{abstract}
This paper describes a cogeneration plant using wood biomass as fuel. Forests cover $56 \%$ of the surface area in Slovenia, providing plenty of waste wood to be used as an energy source. Waste wood unsuitable for the lumber industry is ground into biomass of G50 size, whose chips are on average $3-5 \mathrm{~cm}$ and up to $8 \mathrm{~cm}$. Biomass is dried in a drier to reduce its moisture content to $15 \%$. Wood biomass gasification takes place in a gasifier. Carbon monoxide and hydrogen, gasification end products, are used as fuels for a boiler and two gas engines. The boiler heat is used for wood-drying purposes. The cogeneration plant uses a $1 \mathrm{MW}$ Caterpillar generator set and a 0.45 MW MAN generator set. Cooling water waste heat of both gas engines and exhaust gases are used for heating the wood drier and the nearby residential area.
\end{abstract}

\section{Keywords}

Cogeneration, Wood Gas

\section{Introduction}

The demand for thermal and electrical energy is typically met by supplying power from the local distributor's network and generating heat by burning fuel in a furnace or a boiler. Cogeneration technology, however, provides significant fuel saving and reduction in the emissions of harmful substances into the environment. Cogeneration or combined heat and power (CHP) [1] is the concurrent production of two or more types of useful energy from a single primary energy source. The two most frequently used forms are mechanical energy, used for powering an electric generator, and thermal energy used for heating or for the technological requirements of production in the pharmaceutical and other industries. Three-generation differs from cogeneration in that waste heat is used for both heating and cooling, typically in an absorption refrigerator 
[2] [3].

Large amounts of heat are released into the atmosphere via steam condensers and cooling towers during the operation of conventional power plants. In cogeneration systems using internal combustion engines, however, the waste heat of engines and exhaust gases may be exploited. Most of such thermal energy can be used to meet the demand for heat. The efficiency of a conventional power plant, ranging between $30 \%$ and $40 \%$, is increased to $80 \%-90 \%$ efficiency in a cogeneration system.

For the production of mechanical energy that drives an electric generator, gas turbines are usually used for power levels over $5 \mathrm{MW}$, while for lower levels, a diesel or spark ignition engine is used. Diesel engines are used with diesel fuel or biofuel [4] [5]. A spark ignition engine is used in the case of natural gas [6]. Another variant is the wood gasifier CHP plant in which wood pellet or wood chip biofuel is gasified in a zero oxygen, high temperature environment; the resulting gas is then used to power the gas engine.

In Slovenia, approximately $2 \%$ of electricity is generated using cogeneration systems. Industrial and district heating networks ensure the growth of such technology. Today, many existing systems are outdated, providing myriad opportunities for reconstruction. One concept for the development of households and industry envisages the construction of several small biomass units and the application of natural gas as a fuel with a relatively extensive distribution network. This concept has good development potential in Slovenia [7]. Forests cover $56 \%$ of the surface area in Slovenia, which has, as a result, a lot of waste wood to be turned into biomass. Biomass is an important fuel in Slovenia. Biomass is gasified in a gasifier, and the wood gas obtained is used to power the gas engine.

The most efficient example of the use of biomass is the energy plant in Güssing, Burgenland, Austria, where the total energy demand of the village is met by biomass. Significant power plants include a $2 \mathrm{MW}$ electric power 4.5 MW thermic wood gas generator power plant in Güssing and in nearby Strem, a $0.5 \mathrm{MW}$ electric power $0.5 \mathrm{MW}$ thermic biomass gasification power plant using green silage re-growing raw materials, such as grass, clover, maize and sunflower [8].

This paper describes a biomass cogeneration system as the first of this type in Slovenia (Figure 1), located in Ruše.

\section{Description of a Wood Biomass Cogeneration Plant}

Waste wood ground into biomass is used as input fuel. The schematic diagram of a wood CHP plant and the fuel flow are shown in Figure 2. Wood gas, generated in a gasifier, is used as a fuel for the boiler, producing heat for the wood-drying facility. Most of the wood gas is used for powering the Caterpillar and MAN gas engines. The former drives the $1 \mathrm{MWe}$, and the latter the $450 \mathrm{kWe}$ electric generator. The electricity thus generated is sold to the Slovenian power grid at a price of EUR $0.27 / \mathrm{kWh}$, with the Slovenian government subsidising energy-related facilities with total efficiency exceeding $80 \%$. The generated heat of engine exhaust gases, cooling water, and heat from inter 


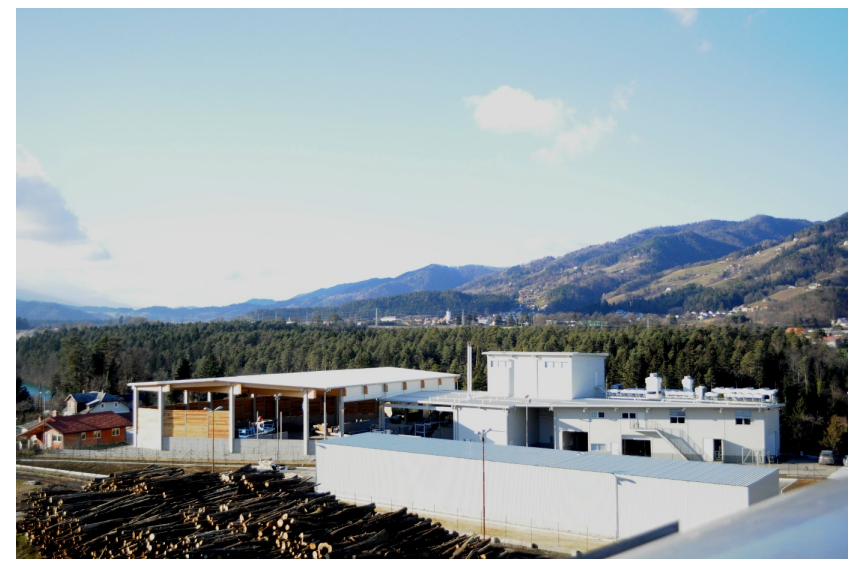

Figure 1. Cogeneration plant.

coolers is used for the wood-drying facility and the heating of a nearby residential area. The heat is sold at a price of EUR $0.02 / \mathrm{kWh}$ (Figure 1).

\section{Drier}

Waste wood unsuitable for lumber industry is in the form of stem wood. The wood has the following composition: $40 \%$ - 50\% cellulose, $20 \%-30 \%$ lignin, and $20 \%-30 \%$ components such as carbohydrates, fats, tannin and minerals.

It is first dried in the open air and then transported by means of a forklift truck to a grinder mill, where it is ground to G50 biomass, i.e. $8 \mathrm{~cm}$ chips, mostly measuring 3 - 5 $\mathrm{cm}$. Subsequently, the biomass is transported to a weekly storage container. It serves as a reservoir with a system that spreads the biomass evenly over the entire storage surface. At its bottom, the container is fitted with a system of movable rods, moving the biomass, by means of a hydraulic pump, towards the outlet from the weekly storage container, where the biomass is discharged onto a conveyer belt. From there, the biomass is fed into a screening machine, where it is divided into three parts: the smallest are used for the biomass boiler and transported by the conveyer belt into the storage container, while the oversized ones are reground. The G50 biomass is transported via the screening-storage container conveyer belt into the biomass storage area. The lower heating value (LHV) of this biomass is $2.7 \mathrm{kWh} / \mathrm{kg}$ and its moisture content $40 \%$. The biomass is transported from here into a drier for pre-drying. The heat for biomass drying is partly provided by the boiler and partly by the heat exchanger, cooling the wood gas from $500^{\circ} \mathrm{C}$ to $300^{\circ} \mathrm{C}$ (Figure 2). The biomass is dried to $15 \%$ of moisture content in the drier, and its lower heating value (LHV) increases to $4.1 \mathrm{kWh} / \mathrm{kg}$. The chemical composition of such biomass is $50 \%$ carbon, $42 \%$ oxygen, $6 \%$ hydrogen, $1 \%$ methane, $1 \%$ nitrogen and minerals. The wood biomass is fed from the drier, where pre-drying takes place, into the gasifier.

\section{Gasification and Wood Gas Preparation System}

A gasifier (Figure 3) is a device in which sawdust and G50 chip gasification process 
takes place. The cylindrical gasifier is a downdraft unit, which means that the wood biomass and wood gas flow in the same direction, namely from the top to the bottom.

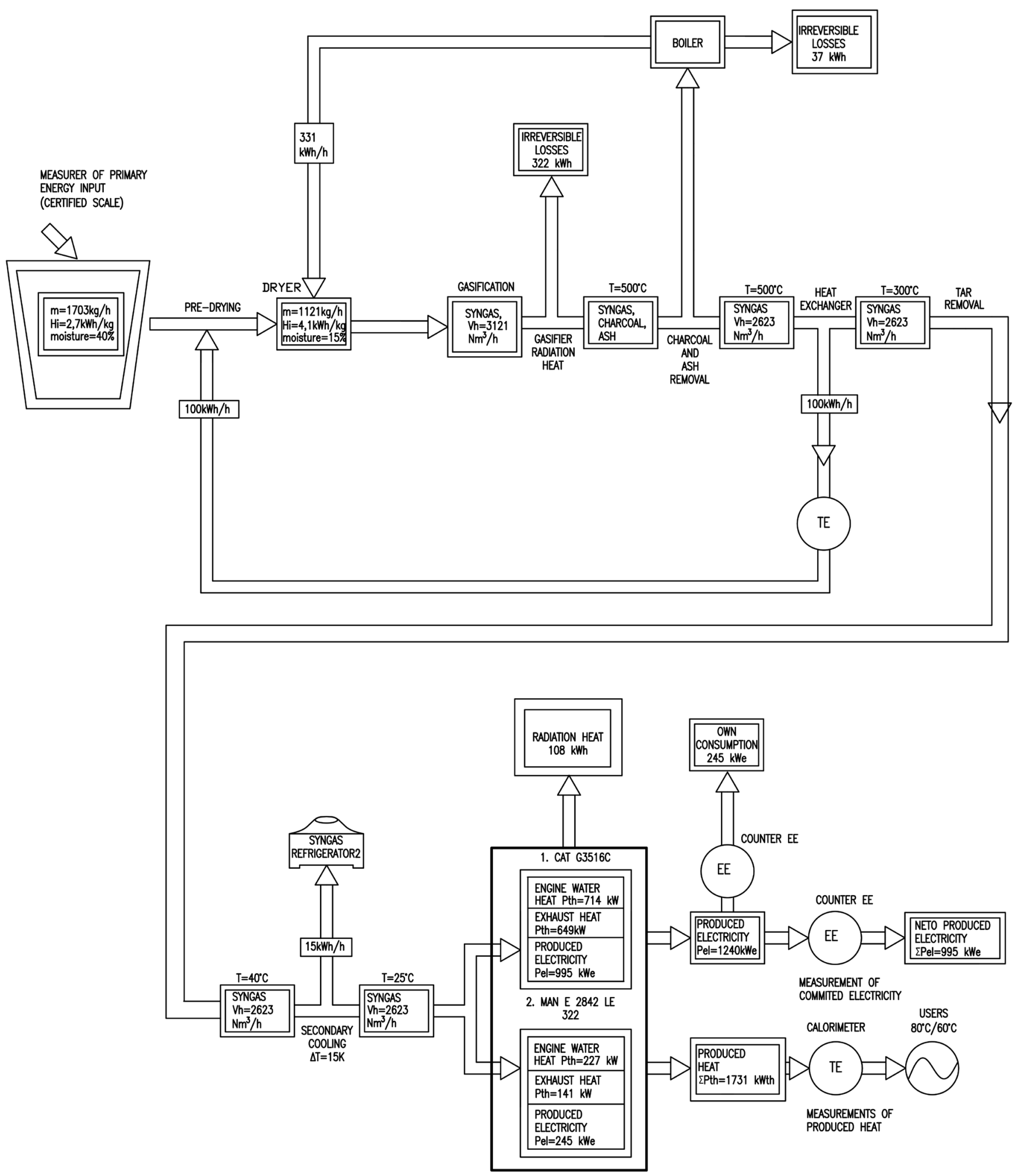

Figure 2. Diagram of the plant and the fuel flow. 


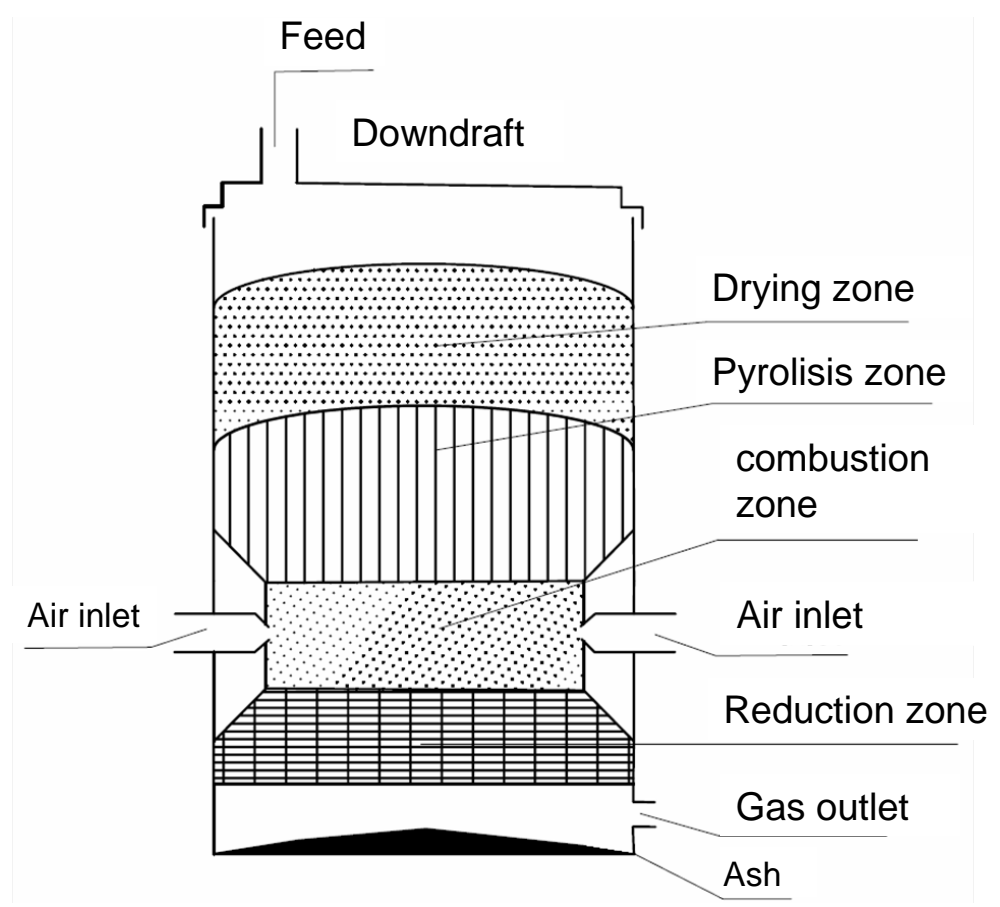

Figure 3. Downdraft gasifier diagram.

The biomass in the form of wood chips is fed by means of conveyer belts and an elevator into a dispenser with double pneumatic flaps. From the dispenser, it enters the upper part of the gasifier via a longitudinal fixed grid.

The wood biomass gasification involves five phases [9] [10]:

1) Biomass drying phase takes place in the drying zone (Figure 3), where biomass is dried at temperatures from $100^{\circ} \mathrm{C}$ to $150^{\circ} \mathrm{C}$. Moisture in the biomass evaporates and in the reduction zone it reacts with carbon to form hydrogen and carbon monoxide.

2) Pyrolysis of the dried biomass takes place in the pyrolysis zone at temperatures from $200^{\circ} \mathrm{C}$ to $500^{\circ} \mathrm{C}$. Pyrolysis is the application of heat to biomass, in an absence of air, so as to break it down into charcoal and various tar gasses and liquids. It is essentially the process of charring. The biomass breaks down into solids, liquids and gases at temperatures of over $250^{\circ} \mathrm{C}$. The solids that remain are charcoal. The gases and liquids that are produced are collectively called tars.

3) The heat needed for drying, pyrolysis and reduction is obtained through combustion in the combustion zone. Tar gases and charcoal from pyrolysis are used as a fuel. The necessary amount of air for combustion is blown into the combustion zone through the nozzles (Figure 3). Cracking of biomass also takes place in this zone. Large molecules, such as tar, break down in this process into lighter gas molecules, whereby heat is intensely supplied. The tar gas break down process is crucial for proper internal combustion engine operation. Heavy molecules of tar gases are condensed at a spark plug and at valves of the engine and cause engine malfunction. Combustion and cracking are running from $800^{\circ} \mathrm{C}$ to $1200^{\circ} \mathrm{C}$. The carbon content in the biomass is the highest and therefore the basic reaction in the combustion zone is 


$$
\mathrm{C}+\mathrm{O} \leftrightarrow \mathrm{CO}_{2}+34 \mathrm{MJ} / \mathrm{kg} \cdot \mathrm{C}
$$

4) Reduction in a gasifier (Figure 3) is accomplished in the reduction zone by passing carbon dioxide or water vapour across a bed of red hot charcoal. The carbon in the hot charcoal is highly reactive with oxygen; it has such a high oxygen affinity that it strips the oxygen off water vapour and carbon dioxide, and redistributes it to as many single bond sites as possible. The oxygen is more attracted to the bond site on the carbon than to itself, thus no free oxygen can survive in its usual diatomic $\mathrm{O}_{2}$ form. All available oxygen will bond to available carbon sites as individual oxygen until all the oxygen is gone. The reduction reactions are

$$
\begin{gathered}
\mathrm{CO}_{2}+\mathrm{C} \rightarrow 2 \mathrm{CO} \\
\mathrm{H}_{2} \mathrm{O}+\mathrm{C} \rightarrow \mathrm{CO}+\mathrm{H}_{2}
\end{gathered}
$$

Through this process, carbon dioxide is reduced by carbon to produce two carbon monoxide molecules, and $\mathrm{H}_{2} \mathrm{O}$ is reduced by carbon to produce $\mathrm{H}_{2}$ and carbon monoxide. Carbon monoxide and hydrogen are end products of a gasifier and used as a fuel for the boiler and both gas engines. The gasifier capacity is $2623 \mathrm{Sm}^{3}$ of wood gas per hour. The temperature of the gas at the outlet from the gasifier is $500^{\circ} \mathrm{C}$. The gasifier waste heat flow is $322 \mathrm{~kW}$.

5) A reactor retains charcoal to reduce some wood gas components due to a higher heating value (LHC), while it allows the ash at the bottom of the gasifier to be discharged. The gasifier is fitted with a grid at the bottom, through which fuel dosing takes place. The gasifier is insulated by a thick layer of thermal concrete and fitted with connections for the lateral air inlet and outlet of gasification products towards the boiler and the engine. Syngas thus generated is too hot and too dirty to enter the internal combustion engines; as a result, it requires adequate prior treatment.

A portion of the gas is fed to the boiler (Figure 2), generating heat for biomass drying. The gas outlet heat power is $368 \mathrm{~kW}$. The remaining amount of gas $\left(2623 \mathrm{Nm}^{3}\right)$ enters the gas-water tubular heat exchanger where it is cooled down from $500^{\circ} \mathrm{C}$ to $300^{\circ} \mathrm{C}$. The heat exchanger thermal capacity is $100 \mathrm{~kW}$ and is used for biomass predrying (Figure 2). Gas is fed from the heat exchanger to a tar removal device. Tar has to be removed from gas as it causes coking at engine spark plugs and plugging of the wood gas-air mixing valve nozzles. After 1200 hours of engine operation, traces of tar and tar combustion products were observed on the engine valves. Wood gas then enters the tubular heat exchanger, where it is cooled down to $40^{\circ} \mathrm{C}$ (Figure 2). This heat is lost in the process; heat losses amount to $344 \mathrm{~kW}$. The gas then enters the dust remover and a series of fine filters. During cogeneration, the filters are replaced on a weekly basis. The filtered gas enters a wood gas cooler 2, where it is cooled down to $25^{\circ} \mathrm{C}$. Gas cooling takes place in the water-wood gas heat exchanger. Afterwards, the filtered and cooled down gas enters the gas engines.

\section{Generator Set}

Cogeneration has two generator sets, a Caterpillar G CAT 3516C with mechanical power 
of $1030 \mathrm{~kW}$ and electric power of $995 \mathrm{~kW}$ and an ER MAN E 2842 LE 322/LSA 47.2 S5 with mechanical power of $270 \mathrm{~kW}$ and electric power of $245 \mathrm{~kW}$ (Figure 2).

The Caterpillar ER CAT 3516C engine exhaust gas flow rate is $7254 \mathrm{~kg} / \mathrm{h}$ and outlet temperature $394^{\circ} \mathrm{C}$. The gases are cooled down to $120^{\circ} \mathrm{C}$ in the tubular heat exchanger. The heat exchanger thermal capacity is $649 \mathrm{~kW}$.

The engine is water cooled. The cooling water flow rate is $42 \mathrm{~m}^{3} / \mathrm{h}$; cooling water also cools the engine oil. The cooling system outlet water temperature is $90^{\circ} \mathrm{C}$ and the inlet temperature $70^{\circ} \mathrm{C}$. The cooling water heat is transformed in a plate heat exchanger into the wood cooling facility heat. The heat exchanger thermal capacity is $694 \mathrm{~kW}$.

The wood gas-air mixture is cooled down in the intercooler from $80^{\circ} \mathrm{C}$ to $40^{\circ} \mathrm{C}$ and additional $20 \mathrm{~kW}$ of thermal power is obtained. The total thermal power of the engine cooling water and the mixture cooling is $714 \mathrm{~kW}$.

The intercooler cooling water flow rate is $20 \mathrm{~m}^{3} / \mathrm{h}$.

The total thermal power of the Caterpillar G CAT 3516C generator set is $1363 \mathrm{~kW}$ and its total efficiency $83 \%$.

The electric generator efficiency is $96.7 \%, \cos \varphi=0.9$.

According to the available information, this is the first Caterpillar generation set application using wood gas.

The ER MAN E 2842 LE 322/LSA 47.2 S5 engine exhaust gas mass flow rate is 1302 $\mathrm{kg} / \mathrm{s}$, with the outlet temperature of $440^{\circ} \mathrm{C}$. Exhaust gases are cooled down to $120^{\circ} \mathrm{C}$ in the tubular heat exchanger. The heat exchanger thermal power is $141 \mathrm{~kW}$.

The engine is water cooled. The cooling water flow rate is $15.2 \mathrm{~m}^{3} / \mathrm{h}$; cooling water also cools the engine oil. The cooling system outlet water temperature is $90^{\circ} \mathrm{C}$ and the inlet temperature $70^{\circ} \mathrm{C}$. The cooling water heat is transformed in a plate heat exchanger into the wood cooling facility heat. The heat exchanger thermal capacity is $227 \mathrm{~kW}$.

The total thermal power of the ER MAN E 2842 LE 322/LSA 47.2 S5 generator set is $368 \mathrm{~kW}$.

The efficiency of the Leroy Sommer LSA 47.2 S5 electric generator is $93.8 \%, \cos \varphi=$ 0.8 .

The generator set total efficiency is $82 \%$.

The total electric power of both generator sets is $1240 \mathrm{~kW}$, and the total thermal power used for heating the drier is $1731 \mathrm{~kW}$.

The outlet water temperature for the wood drier or heating is $80^{\circ} \mathrm{C}$, the inlet temperature is $60^{\circ} \mathrm{C}$, and the mass flow rate $20.6 \mathrm{~kg} / \mathrm{s}$.

\section{Economic Analysis of Cogeneration}

The wood biomass cogeneration investment costs totalled EUR 6 million [11] [12] [13]. Out of the total electric power of $1240 \mathrm{~kW}, 245 \mathrm{~kW}$ of power is used for own consumption and $995 \mathrm{~kW}$ sold into the Slovenian power grid at a price of EUR $0.27 / \mathrm{kWh}$, subsidised by the Slovenian government. Heat is fully sold at a price of EUR $0.02 / \mathrm{kWh}$. The sold electricity generates the highest revenue. The cogeneration plant operates at full capacity $80 \%$ of time in a year or 8760 hours per year or 7008 hours of operation. The 
revenue from the sold electricity is

$$
7008 \text { hours } \times 995 \mathrm{~kW} \times \text { EUR 0.27/kWh }=\text { EUR 1,882, 699.2. }
$$

The revenue from the heat sold is

$$
7008 \text { hours } \times 1713 \mathrm{~kW} \times \text { EUR 0.02/kWh }=\text { EUR 242, 616.96. }
$$

The total revenue is

$$
\text { EUR 242,616.96 + EUR 1,882, } 699.2 \text { = EUR 2,125,316.16 . }
$$

The annual operating costs are estimated at $2 \%$ of the value of investment or EUR 120,000 .

The cogeneration plant employs eight people. The costs of their salaries and personal equipment needed for the maintenance of the facility amount to EUR 200,000 per year.

The primary energy consumption of both cogeneration engines at $82 \%$ efficiency is

$$
(\text { Pel }+ \text { Pheat }) / \mathrm{h}=(1240 \mathrm{~kW}+1731 \mathrm{~kW}) / 0.82=2971 \mathrm{~kW} / 0.82=3623 \mathrm{~kW} .
$$

The biomass consumption of both engines by taking into consideration the below indicated biomass lower heating value (LHC) of $2.7 \mathrm{kWh} / \mathrm{kg}$ and $40 \%$ moisture content is:

$$
\dot{\mathrm{m}}=\frac{\mathrm{P}_{\mathrm{tot}}}{\mathrm{H}_{\mathrm{i}}}=\frac{3623}{2.7 .3600}=0.372 \frac{\mathrm{kg}}{\mathrm{s}}=1431 \frac{\mathrm{kg}}{\mathrm{h}} .
$$

The overall consumption of the system of both engines and the boiler, generating the heat for biomass drying and pre-drying and for covering the losses is $1703 \mathrm{~kg} / \mathrm{h}$ of biomass. The yearly consumption of biomass at 7008 operating hours is $11,934,624 \mathrm{~kg}$. The annual biomass cost at the price of EUR 0.05/ $\mathrm{kg}$ is EUR 596,731.2.

The total efficiency of the entire plant when the consumption of heat for wood drying and pre-drying is taken into account and for powering other auxiliary units is

$$
\frac{\text { Pel }+ \text { Pheat }}{\mathrm{H}_{\mathrm{i}} \cdot \dot{\mathrm{m}}}=\frac{1240 \mathrm{~kW}+1731 \mathrm{~kW}}{2.7 .3600 .0 .473}=0.646 \text {. }
$$

The operating costs, costs of employee salaries and of their equipment and the wood biomass price are

$$
\text { EUR 200,000 + EUR 120,000 + EUR 596, 731.2 = EUR 916, 731.2. }
$$

The cogeneration net annual revenue amounts to

$$
\text { EUR 2,125,316.16 - EUR 916, } 731.2 \text { = EUR 1, 208, 584.96. . }
$$

The investment in cogeneration is repaid in

$$
\frac{6,000,000}{1,408,584.96}=4.96 \text { years. }
$$

\section{Summary}

The paper describes a cogeneration plant for the production of electricity and heat used in a wood drying facility. Heat may also be used for heating in a nearby residential area. Waste wood, in particular stem wood unsuitable for industrial application, is the fuel. 
The cogeneration plant introduced in the paper is the first in Slovenia and one of the first in the world in the power range of up to $1.5 \mathrm{MW}$, operating on biomass.

Waste wood comprising $40 \%-50 \%$ of cellulose, $20 \%-30 \%$ of lignin, $20 \%-30 \%$ of components such as carbohydrates, fats, tannin and minerals is first dried in the open air and then transported into a grinder mill where it is ground to G50 biomass, namely wooden chips with the size of up to $8 \mathrm{~cm}$. The lower heating value (LHC) of the biomass is $2.7 \mathrm{kWh} / \mathrm{kg}$ and its moisture content $40 \%$. Biomass is dried in the drier to moisture content of $15 \%$ prior to entering the gasifier to increase its LHC to $4.1 \mathrm{kWh} /$ $\mathrm{kg}$. The biomass prepared in this fashion has the following chemical composition: 50\% of carbon, $42 \%$ of oxygen, $6 \%$ of hydrogen, $1 \%$ of methane, $1 \%$ of nitrogen and minerals.

The gasifier is of a downdraft model and produces $3121 \mathrm{Nm}^{3}$ of wood gas per hour, containing carbon monoxide and hydrogen as the burning substance. The two gas engines consume $2623 \mathrm{Nm}^{3}$ and the rest is the boiler generating heat for wood drying.

Electricity is generated by two generator sets, namely Caterpillar G CAT 3516C with electric power of $995 \mathrm{~kW}$ and thermal power of $1363 \mathrm{~kW}$ and total efficiency of $83 \%$, and ER MAN E 2842 LE 322/LSA 47.2 S5 with electric power of $245 \mathrm{~kW}$ (Figure 2) and thermal power of $368 \mathrm{~kW}$ and total efficiency of $82 \%$. The cogeneration system consumes $245 \mathrm{~kW}$ of power for own use.

The generated power is sold to the Slovenian power distribution grid at a price of EUR $0.27 / \mathrm{kWh}$, subsidised by the Slovenian government. Heat is fully consumed in the wood drier. The price of the heat sold is low at only EUR $0.02 / \mathrm{kWh}$. Technically speaking, the sale of heat for sanitary water heating and heating of the nearby residential area is also possible. Unfortunately, heat for district heating purposes can only be sold in winter.

The total efficiency of the facility is $64.6 \%$ and the investment is to be repaid in five years.

\section{References}

[1] Sun, Z.G., Wang, R.Z. and Sun, W.Z. (2004) Energetic Efficiency of a Gas Engine-Driven Cooling and Heating System. Applied Thermal Engineering, 24, 941-947. http://dx.doi.org/10.1016/j.applthermaleng.2003.10.014

[2] Havelský, V. (1999) Energetic Efficiency of Cogeneration Systems for Combined Heat, Cold and Power Production. International Journal of Refrigeration, 22, 479-485. http://dx.doi.org/10.1016/S0140-7007(99)00010-9

[3] Hufford, P.E. (1992) Absorption Chillers Improve Cogeneration Energy Efficiency. ASHRAE Journal, 46-53.

[4] Husain, Z., Zainal, Z.A. and Abdullah, M.Z. (2003) Analysis of Biomass-Residue-Based Cogeneration System in Palm Oil Mills. Biomass and Bioenergy, 24, 117-124. http://dx.doi.org/10.1016/S0961-9534(02)00101-0

[5] Hall, D.O., Barnard, G.W. and Moss, P.A. (1982) Biomass for Energy in the Developing Countries. Pergamon Press, Oxford.

[6] Chester, P. (1989) Gas as a Fuel Source in CHP Systems. Energy World.

[7] Zakaria, I. (2002) Renewable Energy Program from National Perspective. Renewable En- 
ergy Power (SREP) Program for Palm Oil Industry, April 2002.

[8] http://www.eee-info.net/cms/netautor/napro4/appl/na_professional/parse.php?mlay_id=25 00\&mdoc_id $=1000558$

[9] Greenhouse Gas Technology Center, Technology Assessment Report: Aqueous Sludge Gasification Technologies, EPA/600/R-12/540 June 2012 Version 1.5.

[10] Tillman, D.A., Rossi, A.J. and Kitto, W.D. (1981) Wood Combustion: Principles, Processes and Economics. Academic Press, New York.

[11] Silveira, J.L., Beyene, A., Leal, E.M., Santana, J.A. and Okada, D. (2002) Thermoeconomic Analysis of a Cogeneration System of University Campus. Applied Thermal Engineering, 22, 1471-1483. http://dx.doi.org/10.1016/S1359-4311(02)00064-9

[12] Sunberg, G. and Henning, D. (2002) Investments in Combined Heat and Power Plants: Influence of Fuel Price on Cost Minimized Operation. Energy Conversion and Management, 43, 639-650. http://dx.doi.org/10.1016/S0196-8904(01)00065-6

[13] Lin, C.F. and Lu, D.H. (2000) Feasibility Analysis of Cogeneration and Combined Heat, Power and Cold for Tulufan City. Gas \& Heat, 20, 303-304. (In Chinese)

\section{Nomenclature}

$\begin{array}{lll}\mathrm{H}_{\mathrm{i}} & \text { lower heating value (LHC) } & {[\mathrm{J} / \mathrm{kg}, \mathrm{kWh} / \mathrm{kg}]} \\ \mathrm{P}_{\mathrm{el}} & \text { electrical power } & {[\mathrm{W}, \mathrm{kW}]} \\ \text { Pheat } & \text { thermal power } & {[\mathrm{W}, \mathrm{kW}]} \\ \dot{\mathrm{m}} & \text { mass flow } & {[\mathrm{kg} / \mathrm{s}]} \\ \mathrm{P}_{\mathrm{t}} & \text { total power } & {[\mathrm{W}, \mathrm{kW}]}\end{array}$
for you:

Accepting pre-submission inquiries through Email, Facebook, LinkedIn, Twitter, etc. A wide selection of journals (inclusive of 9 subjects, more than 200 journals)

Providing 24-hour high-quality service

User-friendly online submission system

Fair and swift peer-review system

Efficient typesetting and proofreading procedure

Display of the result of downloads and visits, as well as the number of cited articles

Maximum dissemination of your research work

Submit your manuscript at: http://papersubmission.scirp.org/

Or contactnr@scirp.org 